\title{
芽胞形成菌におけるジピコリン酸生合成部位 関する研究
}

II) Sporangium 細胞内分画のジピコリン酸生合成能について

川崎 近太郎 近 藤 雅 臣桜 井 純
大阪大学薬学部衛生化学教室

[受付：6月 7 日，1967 年]

\section{緒言}

前報1において芽胞形成過程にともなう細胞内ジピコ リン酸分布の変化について検討した結果, ジピコルン酸 が Sporangium の前駆芽胞をとりまく原形質において 生合成される可能性が示唆された。ジピコリン酸が芽胞 内で生合成される2)のではなく，上述の考え方がもし妥 当であれば，急速にジピコリン酸を生合成しつつある Sporangium から原形質をとりのぞくことにより，ジピ コリン酸生合成を停止させることができるはずである。 また，適当なジピレリン酸前駆物質を Sporangium の細 胞内分画に添加しジピコリン酸合成能を検討するとき， その活性は原形質部位に存在しなくてはならない。この ような考えのもとに，まずリゾチームによる前駆芽胞の 分離法 ${ }^{3)}$ を用い，前駆芽胞のジピコリン酸合成能を検討 して原形質部との関連性を追求するとともに各分画にお けるジピコリン酸合成能をジピコリン酸前駆物質として ジケトピメリン酸 $\mathrm{NH}_{3}$ Complex ${ }^{4)}$ を用いて検討するこ とにした。

\section{実験方法}

Bacillus subtilis NRRL 558 を用い前報と同じ方法で 培養し，芽胞形成を行なわしめた。

リゾチーム処理についても同様に終濃度 $10 \mu \mathrm{g} / \mathrm{ml} の$ $\mathrm{MgCl}_{2}$ および $50 \mu \mathrm{g} / \mathrm{ml}$ のリゾチームを用い溶菌させ た。ジピコリン酸の定量は Janssen ${ }^{5)}$ の方法を用い, ジ ケトピメリン酸はジニトロフェニールヒドラジン法によ り定量した。ジケトピメリン酸はジエチルオキザル酢酸 から Cope' ${ }^{6}$ らの方法により合成した。

ジケトピメリン酸からジピコリン酸の生成反忘は, ジ ケトピメリン酸 $10 \mathrm{mM}$ と $\mathrm{NH}_{4} \mathrm{Cl} 20 \mathrm{mM}$ を含む $\mathrm{M} / 100$
燐酸緩衝液に細胞抽出液を混合し，ワールブルグ検圧計 にて経時的に酸素吸収を測定し4)，その吸収量をむつて あらわす方法と，直接ジピコリン酸の定量あるいはジケ トピメリン酸の消費量を測定する方法により解析した。 蛋白質は Folin 試薬を用い， Lowry の方法?により定 量した。

\section{実験線 果}

ジピコリン酸が芽胞内で生合成されるという Halvorson の仮説23が正しいとすれば，来胞形成過程において 急激なジピコリン酸生合成の行なわれる段階でリゾチー ムを添加し， Sporangium 細胞壁の溶解とそれに伴う原 形質の流出がおこつてもリゾチーム非感受性の芽胞が存 在するかぎりジピコリン酸生合成に何ら影響しないはず である。そこで, 18 時間から 26 時間培養の各時点で培 養液にリゾチームを添加し，その後のジピコリン酸量の 増加を検討した。結果注第 1 図に示してあるが，リゾチ ームを添加せずジピコリン酸量を経時的に定量したとき 急激な増加がみられるにもかかわらず，矢印の時点でリ ゾチームを添加するとただちにジピコリン酸生合成が停 止し，以後全く増量は認められなかつた。つぎにリゾチ ーム共存の影響を除くと同時にリゾチーム不溶性分画体 のジピコリン酸生合成能を検討するため以下の実験を行 なつた。各培養時点小゙集菌し, 遠沈洗浄後 $M / 100$ 粼酸 緩衝液 $(\mathrm{pH} 7.8)$ に䀣濁後リゾチーム処理により溶菌さ せた後この溶菌液を $12,000 \mathrm{rpm}, 20$ 分間冷却遠沈し, 不溶性分画を得た。これを再びもとの培養上清に䀣濁 し, $35^{\circ} \mathrm{C}$, 振とう培養してその後のジピコリン酸量の変 化を経時的に測定したところ第 2 図のような結果が得ら れた。この結果からどの培養時点で採取した菌体もリゾ チーム不溶性分画のみではジピコリン酸を生合成するこ 


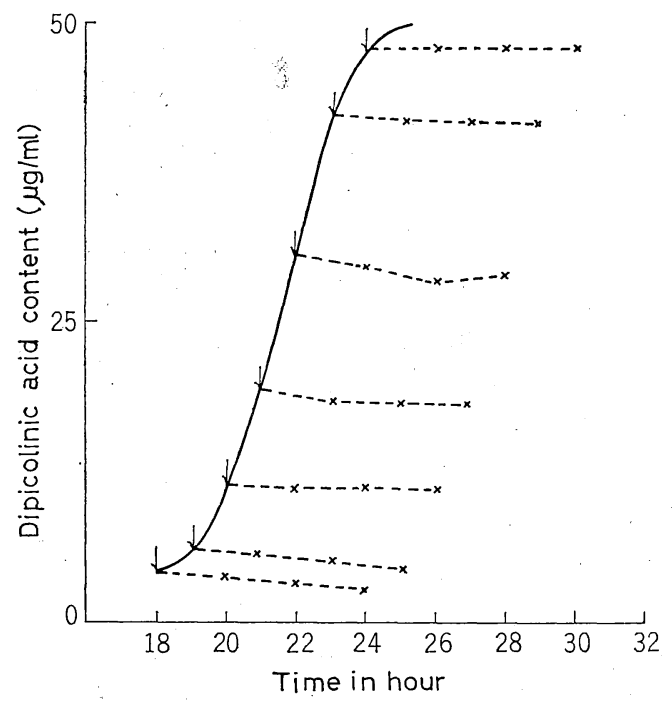

第 1 国 リゾチーム添加によるジピコ リン酸生合成の停止

註 : 矢印はリゾチーム添加時期を示す

○一|リゾチーム無添加におけるジピコ リン酸総量の変化を示す

$\times \cdots \times$ リゾチーム添加後のジピコリン酸 量の変化を示す

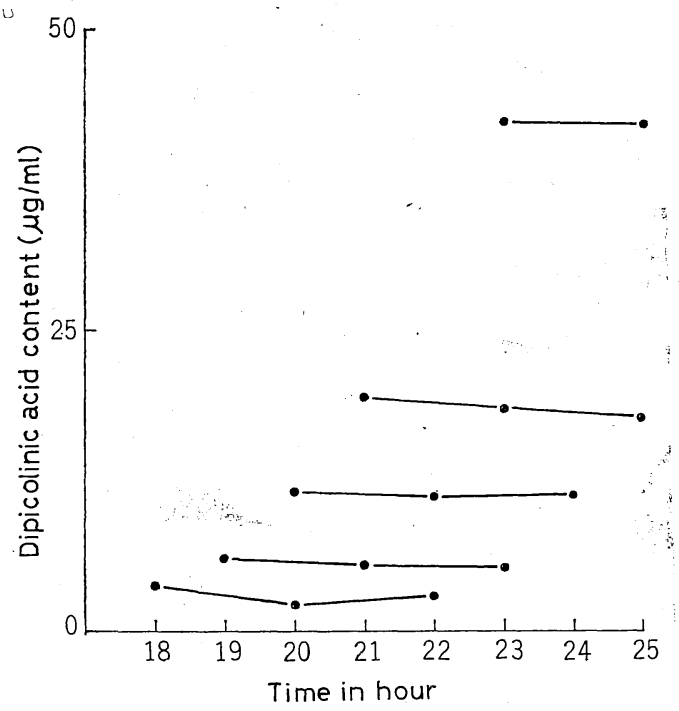

第 2 図 芽胞形成各時点の細胞から分離し たリゾチーム不溶性分画によるジ ピコリン酸合成能

とはできないことが明らかとなつた。

以上ジピコリン酸が急激に増加しているような培養時 点においても，一度リゾチームが添加されるとジピコリ ン酸生合成がただちに停止すること，また，ジピコリン

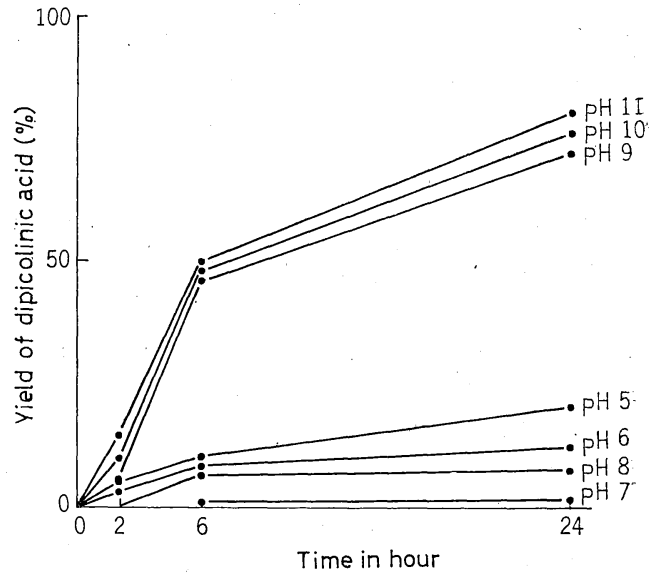

第 3 図 Diketopimelate- $\mathrm{NH}_{3}$ complex からの ジピコリン酸自働合成におよぼす $\mathbf{p H}$ の影響

註：ジケトピメリン酸, $10 \mathrm{mM}, \mathrm{NH}_{4} \mathrm{Cl} ; 20 \mathrm{mM}$ を各種 $\mathrm{pH}$ に調製した緩衝溜に溶解し, $37^{\circ} \mathrm{C}$ にて保温し経時的にジピコリン酸生 成量を測定した

酸が増加し得るような培地の状態においてもリゾチーム。 不溶性分画すなわち前駆芽胞あるいは成熟芽胞 ${ }^{3}$.のみで はジピコリン酸生合成がみられないことから，芽胞形成， にともなうジピコリン酸の生合成には少なくとも前駆芽 胞をとりまく原形質の存在が必要であることを示唆して いる。この推察がもし正しいとすれば適当なジピコリン 酸前駆物質をリゾチーム可溶性分画に添加すれば in vitro でジピコリン酸の合后市がおこるはずである。ジピ コリン酸前駆物質については Powell'sが B. careus の 機械的磨砕により得られる無細胞抽出液にジケトピメリ ン酸と $\mathrm{NH}_{4} \mathrm{Cl}$ を添加するとジヒドロジピコリン酸を経 由してジピコリン酸が生成されることを報じているので この反応系を利用してリゾチーム可溶性分画および不溶 性分画についてジピコリン酸合成能を検討した。

ジケトピメリン酸 $10 \mathrm{mM}$ および $\mathrm{NH}_{4} \mathrm{Cl} 20 \mathrm{mM}$ を含 む $\mathrm{M} / 100$ 燐酸緩衝液（pH 7.0）にリゾチーム可溶性お よび不溶性分画を混合し Powell ${ }^{4)}$ の酸素吸収によるジピ コリン酸生成の活性測定法とジピコリン酸を直接定量す る方法とを同時に行ないそれぞれのジピコリン酸生成能 を比較した。この際ジケトピメリン酸の化学構造から $\mathrm{NH}_{4} \mathrm{Cl}$ の共存下で自働的にジピコリン酸が生成される 可能性が考えられるので，まず，この反応系に細胞分画 を添加せずジピコリン酸自動生成の可否を反応溶液の $\mathrm{pH}$ をかえて検討した。結果は第 3 図に示すとおりであ る。 
すなわち，この反応においてアルカリ性では長期間の 振盪によりかなりのジピコリン酸が自働生成され，また 酸性域においても若干のジピコリン酸生成がみられた が，中性では 4 時間以内では全くジピコリン酸の生成が みられなかった。しかも， $\mathrm{pH} 7.0$ の反応溶液にリゾチ 一ム可溶性分画を添加すると急激な酸素吸収を伴なって ジピコリン酸が生成され，その生成量は 30 分で極大に 達することが判明した(第 1 表)。

表 1. リゾチーム可溶性分画添加時の Diketopimelate- $\mathrm{NH}_{3}$ complex らのジピコリン酸合成

\begin{tabular}{|c|c|c|c|}
\hline $\mathrm{pH}_{\mathrm{pH}}^{\text {保温 }(\mathrm{min})}$ & 30 & 90 & 150 \\
\hline $\begin{array}{l}\text { 無細胞抽出液無 } \\
\text { 添加 (各 } \mathrm{pH})\end{array}$ & $0^{*}$ & 0 & 0 \\
\hline 6.0 & 34.0 & 34.0 & 34.0 \\
\hline 7.0 & 38.0 & 38.0 & 40.0 \\
\hline 8.0 & 32.0 & 32.0 & 32.0 \\
\hline
\end{tabular}

*添加したジケトピメリン酸から生成され 得るジピコリン酸計算量を 100 として区 応により生成されたジピコリン酸の百分 率として示した。

このように $\mathrm{pH} 7.0$ の反応溶液中ではジピコリン酸の 自働生成を全く考慮する必要がなく，また，リゾチーム 可溶性分画の添加によりジピコリン酸生成が認められる ことがわかつたのでこの反応条件を用いて芽胞形成各過 程の細胞内分画についてジピコリン酸生成能を比較検討 することにした。

芽胞形成各過程の細胞を集め, リゾチーム処理後, $12,000 \mathrm{rpm}, 20$ 分閒冷却遠沈して上清と沈渣に分離し, その各々についてジピコリン酸生成能を比較した。第 4 図はその結果を示しているが，ジピコリン酸生成に関与 する活性物質はすべて上清部分すなわちリゾチーム可溶 性分画にあり不溶性分画には全く認められなかつた。し かもその活性はジピコリン酸を含有しない栄養型細胞に は認められず，芽胞形成直前すなわちジピコリン酸生合 成の初期において最高となり，ジピコリン酸生合成の完 了に近づくに従つて低下してくることが明らかとなつ た。このように芽胞形成初期の細胞原形質が in vitro でジケトピメリン酸- $\mathrm{NH}_{3}$ Complex からジピコリン酸 を合成し，前駆芽胞あるいは成熟芽胞がこの能力を有し ないことが明らかとなり，さらにリゾチーム不溶性分画 の機械的磨䂶抽出液も全く合成能を有しないことから芽 胞形成にともなうジピコリン酸の生合成において前駆芽

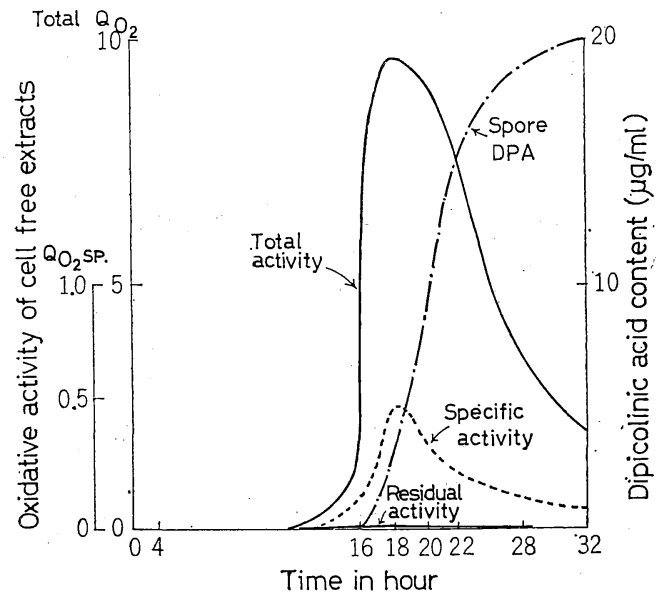

第 4 図 Diketopimelate- $\mathrm{NH}_{3}$ complex 酸化活 性の細胞内分布と芽胞形成にともなう その変働

註 : Total Qo2: $\mu \mathrm{l}$ uptake/mg protein/min

Qo2 sp : $\mu \mathrm{l} \mathrm{O}_{2}$ uptake/ml

胞をとりまく原形質が主役を演ずるものと考えられる。

ジケトピメリン酸からジピコリン酸を合成する活性物 質は $100^{\circ} \mathrm{C} ， 30$ 分の加熱では失活せず，またプロナーゼ 処理によつても失活しないことから酵素の可能性は否定 される。しかもこの活性物質が透析膜を通過すること， 灰化により失活することなどから比較的低分子の有機物 質であることが推察される。この物質の本体については 現在検討中である。

\section{考察}

芽胞形成菌に お方 し，Bach ら ${ }^{87}$ は芽胞形成期の 細胞の無細胞抽出液を用 いピルビン酸とアスパラギン酸セミアルデヒドからジヒ ドロジピコリン酸を経由してジピコリン酸が合成される ことを報告し，また Powell14もジケトピメリン酸- $\mathrm{NH}_{3}$ Complex かららジヒドロジピコリン酸を経由してジピコ リン酸が合成されることを明らかにしている。いずれの 研究においても芽胞形成期の細胞の可溶性部分にジピコ リン酸生合成系が存在することは明らかであるが，しか し，細胞内のどの部位でジピコリン酸が生合成されるか については明らかにされていない。ジピコリン酸生合成 部位に関しては芽胞内で生成されるとする Halvorson 2) の記載があるのみで，乙かも，これは実験的根拠はな い。もしこの仮説が正しいとすれば，Sporangium から 原形質部が流出し，前駆芽胞がのこつた状態においても 
ジピコリン酸生合成が継続されなければならないはずで ある。しかし，本研究においてジピコリン酸が急速に生 合成されている時期にリゾチームを添加し原形質部を流 出させるとジピコリン酸生合成が全く停止すること, ま た, “前報3)の方法により分離した前駆芽胞が全く生合成 能を有しないことが明らかとなり，ジピコリン酸生合成 には前駆芽胞よりむしろそれをとりまく原形質が主役を 演ずることが明らかとなつた。一方，ジピコリン酸前駆 物質からのジピコリン酸合成能を検討した際, 前駆芽胞 は合成能をむたず，原形質部に顕著な合成能が認められ たことはこの考え方をさらに裏付けるものといえ, 従来 の仮説は否定さるべきものと考えられる。Sporangium 原形質部においてジケトピメリン酸- $\mathrm{NH}_{3}$ Complex から ジピコリン酸が合成されるとき，急激な酸素吸収をとも なうことはこの部分に存在する物質がジヒドロジピコリ ン酸の脱水素に関与するものと考えられ，ジピコリン酸 生合成の最終反応を促進する物質と考えられる。この活 性が栄養型細胞にはなくジピコリン酸生合成の開始と同 時に Sporangium 原形質に出現しジピコリン酸生合成 の完了にともなつて消滅することはジピコリン酸生合成 と活性物質との間に直接的関係のあることを示唆してい る。定性的実験からこの活性物質は酵素ではなく比較的 低分子の有機物質であることが明らかであり，また最近 の研究においてこの物質とジピコリン酸合成量との間に
定量的関係のあることも判明し，この物質の存在量が成 熟芽胞中のジピコリン酸量祀 Control する可能性が予 想される。本物質の化学構造の決定については現在検討 中である。

終りにのぞみ想切なる御意見索賜わつた大阪大学微 生物病研究所米田正彦教授に感謝します。本研究の一部 は昭和 42 年度文部省科学研究費各個研究によるもので ある。

\section{文献}

1）川崎近太郎, 近藤雅臣, 西原力: 日本細菌学雑: 誌投稿中.

2) Halvorson, H. : Spores II, p. 149, Burgess: Publishing Company, 1961.

3）川崎近太郎, 近藤雅臣, 手島邦和：日本細菌学 雑誌投稿中.

4) Powell, J. F. and R. E. Strange: Nature, 183, 878, 1958.

5) Janssen, F. W., A. J. Lund and L. E. Anderson: Science, 127, 26, 1958.

5) Cope, A. C. and A. Fournier Jr. : J. Am. Chem. Soc., 79, 3896, 1957.

7) Lowry, O. H., N. J Rosenbrough, A. L. Forr and R. T. Randall : J. Biol. Chem., 193, 265, 1951.

8) Bach, M.L. and C. Gilvarg: J. Biol. Chem., 241, 4563, 1966. 


\title{
Studies on a Biosynthethic Site in Dipicolinic Acid Formation by Bacterial Spore Formers \\ II) Dipicolinic Acid Synthesis by Subcellular Fractions isolated from Sporangium
}

\author{
Chikataro KAWASAKI, Masaomi KONDO and Jun SAKURAI \\ (Faculty of Pharmaceutical Sciences, Osaka University)
}

The participation of sporangial cytoplasm in dipicolinic acid biosynthesis was studied. When lysozyme was added to sporulating culture of $B$. subtilis at various stages, the further synthesis of dipicolinic acid was immediately and almost completely inhibited. It was also found that, when isolated forespores were incubated in culure supernatant obtained from sporulating culture, dipicolinic acid was not synthesized.

The changes in the distribution of the diketopimelate oxidation system in cells were studied. The oxidative activity was found in the soluble fraction and not in the residue fraction during all stages of sporulation. The activity was not detected in mechanical disintegrates of forespores and also in lysozyme lysates of the vegetative cells, and the activity suddenly emerged just before the onset of sporulation. The active substance was supposed to be low molecular organic substance by qualitative analyses. From the above results, it was concluded that the cytoplasm surrounding the developing spore is required for dipicolinic acid synthesis. 